\title{
Click chemistry compared to thiol chemistry for the synthesis of site-selective glycoconjugate vaccines using $\mathrm{CRM}_{197}$ as carrier protein
}

\author{
G. Stefanetti ${ }^{1}$ (D) $\cdot$ M. Allan ${ }^{2} \cdot$ A. Usera ${ }^{2} \cdot$ F. Micoli $^{3}$
}

Received: 13 February 2020 /Revised: 15 April 2020 / Accepted: 30 May 2020 / Published online: 13 June 2020

(C) The Author(s) 2020

\begin{abstract}
Conjugation chemistry is one of the main parameters affecting immunogenicity of glycoconjugate vaccines and a rational approach toward a deeper understanding of their mechanism of action will greatly benefit from highly-defined and wellcharacterized structures. Herein, different conjugation methods were investigated with the aim of controlling glycosylation site and glycosylation density on the carrier protein. $S$. Typhimurium lipopolysaccharide O-Antigen and $C_{R M} M_{197}$ carrier protein were used as models. In particular, thiol and click chemistry were examined, both involving the linkage of the terminal reducing sugar unit of the O-Antigen chain to different amino acids on the carrier protein. Thiol chemistry allowed O-Antigen conjugation only when the carrier protein was activated on the lysines and with a relative high number of linkers, while click chemistry allowed conjugate generation even when just one position on the protein was activated and to both lysine and tyrosine sites. The study highlights click chemistry as a leading approach for the synthesis of well-defined glycoconjugates, useful to investigate the relationship between conjugate design and immune response.
\end{abstract}

Keywords Glycoconjugate vaccine · Click chemistry · Thiol chemistry · Conjugation chemistry · Salmonella Typhimurium . O-antigen $\cdot \mathrm{CRM}_{197}$

\section{Introduction}

Glycoconjugate vaccines are important therapeutics for the prevention of infectious disease from severe pathogens like Neisseria meningitidis, Haemophilus influenza and Streptococcus pneumoniae [1,2]. They require the covalent linking of a sugar antigen to a carrier protein, which can be obtained by different strategies influencing both the efficiency of conjugation and the structure of the glycoconjugate, with an important impact on immunogenicity [3]. Traditional glycoconjugate approaches involve random linkage of the sugar

G. Stefanetti

giuseppe_stefanetti@hms.harvard.edu

1 Department of Immunology, Blavatnik Institute, Harvard Medical School, Boston, MA 02115, USA

2 Novartis Institutes for BioMedical Research, 250 Massachusetts Avenue, Cambridge, MA 02139, USA

3 GSK Vaccines Institute For Global Health (GVGH) S.r.l, Via Fiorentina 1, Siena 53100, Italy hapten to a carrier protein, or end-group modification of the saccharide chain to achieve better control and characterization of the resulting vaccine. More defined constructs where the covalent linking between sugar and the protein is limited to wellestablished attachment sites are highly desirable. They allow a better characterization of the product by physicochemical techniques facilitating the control of manufacturing consistency. Furthermore, the role of glycosylation site on the protein still has to be fully understood and such well-defined products can support studies to further investigate the relationship between glycoconjugate design and immune response. Hence, increasing attention has been made to control the conjugation site [4-6] and provide structurally-defined products not only in their saccharide component but also in the attachment point to the protein [6-9].

We have recently synthesized well-defined O-antigen $(\mathrm{OAg})$-based glycoconjugate vaccines to protect against nontyphoidal Salmonella (NTS) serovar Typhimurium, with $\mathrm{CRM}_{197}$ as carrier protein [6]. NTS is the commonest cause of invasive bacteremia in Africa [10,11], particularly affecting young children and HIV-infected adults, and OAg-based glycoconjugates represent a leading approach for the development of a vaccine against NTS [12-15]. 
Importantly, we found that site-selective single or double attachment of OAg to $\mathrm{CRM}_{197}$ was enough to generate levels of functional antibodies in mice, with titers comparable to the $\operatorname{IgG}$ induced by more complex random conjugates, and that the attachment site on the carrier protein plays a role on the immunogenicity.

In this study we compared four different orthogonal conjugation chemistries for the generation of selective OAg-based glycoconjugate vaccines against NTS, with the aim to identify efficient strategies to link a different number of sugar chains to defined amino acid sites on the protein. In all the constructs, $S$. Typhimurium OAg was end-terminally conjugated to $\mathrm{CRM}_{197}$ as carrier protein via the KDO (3-deoxy-D-mannooctulosonic acid) unit. $\mathrm{CRM}_{197}$ is a $58 \mathrm{kDa}$ nontoxic mutant of diphtheria toxin and was selected as carrier protein for this investigation because of its defined structure and extensive use for licensed glycoconjugate vaccines and other vaccines in development $[16,17]$.

Two methods used refer to thiol chemistry, the thiolmaleimide addition and thioalkylation with halides, while two methods were based on the Huisgen 1,3-dipolar cycloaddition, which was investigated both copper-catalyzed and by the strain promoted variant. Click chemistry has been used for the synthesis of glycoconjugate vaccines only in recent times $[6,8,9,18]$, while the generation of a stable thioether bond by thiolmaleimide addition [19] or thioalkylation with halides [20, 21] are more common conjugation strategies which have been also used for the development of licensed glycoconjugate vaccines against Haemophilus influenza type b [19, 20].

Differently from thiol chemistry, strain promoted copperfree click chemistry resulted in an efficient coupling strategy both in regulating the glycosylation density on the final conjugate and in selectively targeting determined amino acid sites on the carrier protein.

\section{Materials and methods}

\section{Reagents}

The following chemicals were used in this study: cystamine dihydrochloride, 1-ethyl-3-(3-dimethylaminopropyl)carbodiimide ( ED A C ), ( + )-sodium L-a scorbate, $2-(\mathrm{N}-$ morpholino)ethanesulfonic acid (MES), N-hydroxysuccinimide (NHS), tris(2-carboxyethyl)phosphine hydrochloride solution (TCEP), propargylamine, copper(II) sulfate pentahydrate $\left(\mathrm{CuSO}_{4} \cdot 5 \mathrm{H}_{2} \mathrm{O}\right)$, tris(3-hydroxypropyltriazolylmethyl)amine (THPTA), phosphate buffer solution (PBS), adipic acid dihydrazide $(\mathrm{ADH})$, sodium cyanoborohydride $\left(\mathrm{NaBH}_{3} \mathrm{CN}\right)$, dimethyl sulfoxide (DMSO), sodium phosphate monobasic $\left(\mathrm{NaH}_{2} \mathrm{PO}_{4}\right)$ [Sigma]; triplex III (EDTA) [Merck]; N-[ $\beta$ maleimidopropionic acid] hydrazide trifluoroacetic acid salt (BMPH) [Thermo]; $\mathrm{N}-[\varepsilon$-maleimidocaproyloxy]succinimide ester (EMCS), succinimidyl 3-(bromoacetamido)propionate (SBAP),
NHS-PEG4-N 3 [Pierce], Click-easyTM BCN Nhydroxysuccinimide ester I (BCN NHS I) [Berry \& Associates]; DL-1,4-Dithiothreitol (DTT) [Invitrogen]. $\mathrm{CRM}_{197}$ was obtained from Novartis Vaccines and Diagnostics (NV\&D).

\section{$\mathrm{OAg}$ purification and characterization}

$S$. Typhimurium OAg was purified as previously described [22], following fermentation of the animal-derived isolate 2192, obtained from the University of Calgary. OAg resulted pure from proteins $(<1 \% \mathrm{w} / \mathrm{w}$ by micro $\mathrm{BCA})$, nucleic acids $\left(<1 \% \mathrm{w} / \mathrm{w}\right.$ by $\left.\mathrm{A}_{260}\right)$ and endotoxins $(<0.1 \mathrm{UL} / \mu \mathrm{g}$ by LAL). 2192 OAg was fully characterized [23]: it showed an average molecular weight of $20.5 \mathrm{kDa}$ based on HPLC-SEC analysis dRI profile with dextrans as standard, was 100\% O-acetylated on C-2 abequose and 24\% glucosylated. Amino groups were detected by TNBS colorimetric method $[24,25]$ probably as pyrophosphoethanolamine residues in the core region, with a molar ratio of 0.38 respect to $\mathrm{N}$-acetyl glucosamine, unique sugar of the core [23].

\section{Synthesis and characterization of derivatized $\mathrm{CRM}_{197}$}

\section{$\mathrm{CRM}_{197}-\mathrm{BMPH}$ via EDAC chemistry}

$\mathrm{CRM}_{197}$ was solubilized in MES $500 \mathrm{mM} \mathrm{pH} 6.0(12 \mathrm{mg} /$ $\mathrm{mL}$ ); BMPH (42 mg/mL, molar ratio BMPH/COOH groups $\left.\mathrm{CRM}_{197}=10.42\right)$ and $\mathrm{EDAC}(3 \mathrm{mg} / \mathrm{mL}$, molar ratio EDAC/ $\mathrm{COOH}$ groups $\left.\mathrm{CRM}_{197}=1.15\right)$ were added. Mixture was stirred for $1 \mathrm{~h}$ at RT, and then purified by desalting against $\mathrm{NaH}_{2} \mathrm{PO}_{4} 100 \mathrm{mM}$ EDTA $10 \mathrm{mM} \mathrm{pH} 7.0$ on a HiPrep 26/10 desalting column $53 \mathrm{~mL}$, prepacked with Sephadex G-25 Superfine (G-25 $53 \mathrm{~mL})$ [GE Healthcare].

\section{$\mathrm{CRM}_{197}-\mathrm{BMPH}$ via EDAC/NHS chemistry}

$\mathrm{CRM}_{197}$ was solubilized in MES $600 \mathrm{mM} \mathrm{pH} 6.0$ (15.56 $\mathrm{mg} / \mathrm{mL})$; NHS $(10.8 \mathrm{mg} / \mathrm{mL}$, molar ratio $\mathrm{NHS} / \mathrm{COOH}$ groups $\left.\mathrm{CRM}_{197}=5.36\right)$ and $\mathrm{EDAC}(6.2 \mathrm{mg} / \mathrm{mL}$, molar ratio $\mathrm{EDAC} / \mathrm{COOH}$ groups $\mathrm{CRM}_{197}=1.83$ ) were added and the solution mixed at RT for $1 \mathrm{~h}$. After this time, BMPH $(2.8 \mathrm{mg} / \mathrm{mL}$, molar ratio BMPH/COOH groups $\mathrm{CRM}_{197}=0.53$ ) was added and the solution stirred for $2 \mathrm{~h}$ at RT. The mixture was purified by desalting on a PD-10 desalting column (PD 10) [GE Healthcare] against $\mathrm{NaH}_{2} \mathrm{PO}_{4} 100$ mM EDTA $1 \mathrm{mM}$ pH 7.0.

\section{$\mathrm{CRM}_{197}$-EMCS}

$\mathrm{CRM}_{197}$ was solubilized in $\mathrm{NaH}_{2} \mathrm{PO}_{4} 100 \mathrm{mM}$ EDTA $1 \mathrm{mM}$ pH $8.0(4.7 \mathrm{mg} / \mathrm{mL})$; EMCS was added $(0.19 \mathrm{mg} / \mathrm{mL}$, molar ratio EMCS/Lysine groups on $\left.\mathrm{CRM}_{197}=0.2\right)$ after being solubilized in DMSO (final DMSO concentration of $6 \% \mathrm{v} / \mathrm{v}$ ). 
Mixture was stirred for $2 \mathrm{~h}$ at RT, and then purified by desalting (G-25 $53 \mathrm{~mL}$ column) against $\mathrm{NaH}_{2} \mathrm{PO}_{4} 100 \mathrm{mM}$ EDTA $1 \mathrm{mM}$ pH 7.0.

\section{$\mathrm{CRM}_{197}-\mathrm{SBAP}$}

$\mathrm{CRM}_{197}$ was solubilized in $\mathrm{NaH}_{2} \mathrm{PO}_{4} 100 \mathrm{mM}$ EDTA $1 \mathrm{mM}$ pH $8.0(4.7 \mathrm{mg} / \mathrm{mL})$; SBAP was added $(0.3 \mathrm{mg} / \mathrm{mL}$, molar ratio SBAP/Lysine groups on $\left.\mathrm{CRM}_{197}=0.3\right)$ after being solubilized in DMSO (final DMSO concentration of $4 \% \mathrm{v} / \mathrm{v}$ ). Mixture was stirred for $3 \mathrm{~h}$ at RT, and then purified by desalting (G-25 $53 \mathrm{~mL}$ column) against $\mathrm{NaH}_{2} \mathrm{PO}_{4} 100 \mathrm{mM}$ EDTA $1 \mathrm{mM}$ pH 7.0.

$\mathrm{CRM}_{197}-\mathrm{N} 3$ by controlled insertion of linkers on Lys $(+3.8,+$ $5.2,+7.1$ and +10 )

$\mathrm{CMR}_{197}$ was solubilized in $\mathrm{NaH}_{2} \mathrm{PO}_{4} 400 \mathrm{mM} \mathrm{pH} 7.2(20 \mathrm{mg} /$ $\mathrm{mL}$ ), and NHS-PEG4- $\mathrm{N}_{3}$ was added (linker solubilized in DMSO with final DMSO concentration in the mixture of $1 \% \mathrm{v} / \mathrm{v})$. Different amount of NHS-PEG4-N $\mathrm{N}_{3}$ were used to achieve a different degree of derivation on the protein with a molar ratio NHS-PEG4-N N $_{3} /$ Lysine groups $\mathrm{CRM}_{197}$ of 0.18 , $0.26,0.39$, respectively. After mixing at RT for $8 \mathrm{~h}$, the mixture was purified by desalting on a $\mathrm{G} 2553 \mathrm{~mL}$ column against $\mathrm{NaH}_{2} \mathrm{PO}_{4} 100 \mathrm{mM}$ pH 7.2.

\section{$\mathrm{CRM}_{197}$-maleimide}

4-(4-(2,5-dioxo-2,5-dihydro-1H-pyrrol-1-yl)butyl)-3H-1,2,4triazole-3,5(4H)-dione [26] (20 $\mathrm{mM}$ in $\mathrm{CH}_{3} \mathrm{CN}$, freshly prepared) was added dropwise, sequentially every minute in 10 copies, to a solution of $\mathrm{CRM}_{197}$ at $4{ }^{\circ} \mathrm{C}(0.85 \mathrm{mg} / \mathrm{mL}$ in Tris $\mathrm{HCl} 500 \mathrm{mM} \mathrm{pH} \mathrm{7.4),} \mathrm{targeting} \mathrm{tyrosine} \mathrm{resiudes} \mathrm{with} \mathrm{a} \mathrm{molar}$ ratio to $\mathrm{CRM}_{197}$ of $5: 1$. The mixture was stirred at $4{ }^{\circ} \mathrm{C}$ for 15 min and then desalted on Zeba $7 \mathrm{~K}$ MWCO spin column [Pierce] with PBS pH 7.4 as the eluting buffer for three times.

\section{$\mathrm{CRM}_{197}-\mathrm{N} 3$ by selective insertion of linkers on Lys $(+1)$}

$\mathrm{CRM}_{197}-\mathrm{N}_{3}$ was synthesized as previously reported [6]. In brief, the linker ZQG-NH-PEG3-N3 was first synthesized and characterized [6]. $\mathrm{CRM}_{197}(32 \mathrm{mg} / \mathrm{mL}, 32 \mu \mathrm{L})$ was then added to ZQG-NH-(PEG)3-N3 $(2 \mathrm{mg} / \mathrm{mL}, 1 \mathrm{~mL})$ in Tris $100 \mathrm{mM} \mathrm{pH} 8$ and $100 \mu \mathrm{L}$ of mTGase (stock of $50 \mathrm{mg} / \mathrm{mL}$ in PBS prepared from commercial $1 \%$ mTGase in maltocyclodextrin) were added. Reaction was incubated at $25^{\circ} \mathrm{C}$ for $18 \mathrm{~h}$. The mixture was purified by size exclusion chromatography (SEC) on Superdex 200 10/300GL column, with PBS as running buffer. One addition of the linker was observed by Mass Spectrum. LCMS calculated: 58929; observed: $[\mathrm{M}+1] 58929$.

\section{Characterization of derivatized CRM $_{197}$}

Protein content was estimated by micro BCA (using BSA as standard and following manufacturer's instructions [Thermo Scientifics]). HPLC-SEC analysis was used to compare derivatized protein with underivatized $\mathrm{CRM}_{197}$. All samples were eluted on TSK gel G3000 PWXL column $(30 \mathrm{~cm} \times 7.8$ mm; particle size $7 \mu \mathrm{m}$; cod. 808021) with TSK gel PWXL guard column $(4.0 \mathrm{~cm} \times 6.0 \mathrm{~mm}$; particle size $12 \mu \mathrm{m}$; cod.808033) (Tosoh Bioscience). The mobile phase was $0.1 \mathrm{M} \mathrm{NaCl}, 0.1 \mathrm{M} \mathrm{NaH}_{2} \mathrm{PO}_{4}, 5 \% \mathrm{CH}_{3} \mathrm{CN}, \mathrm{pH} 7.2$ at the flow rate of $0.5 \mathrm{~mL} / \mathrm{min}$ (isocratic method for $30 \mathrm{~min}$ ). Void and bed volume calibration was performed with $\lambda$-DNA ( $\lambda$-DNA Molecular Weight Marker III 0.12-21.2 Kbp, Roche) and sodium azide $\left(\mathrm{NaN}_{3}\right.$, Merck), respectively. Protein peaks were detected at $214 \mathrm{~nm}$ and $280 \mathrm{~nm}$ (UV detection) and using tryptophan fluorescence (emission spectrum at $336 \mathrm{~nm}$, with excitation wavelength at $280 \mathrm{~nm}$ ). Linker average loading on $\mathrm{CRM}_{197}$ was determined by MALDI-TOF analysis. For MALDI-TOF analysis, the protein was diafiltrated, using a Centricon-10 (Millipore), against $\mathrm{NaH}_{2} \mathrm{PO}_{4} 10 \mathrm{mM}$ pH 7.2. Two microliters of protein (at a concentration of $5 \mathrm{mg} / \mathrm{mL}$ ) were mixed with $2 \mu \mathrm{L}$ of a saturated solution of sinapinic acid in 50\% acetonitrile solution containing $0.1 \%$ TFA. Two microliters of the mix were spotted on a MTP 384 stainless steel target (Bruker Daltonics GmbH, Bremen, Germany) and allowed to air-dry. Measurements were recorded on an Ultraflex III (Bruker GmBH) MALDI-TOF/TOF MS in linear mode. External calibration was performed by spotting $2 \mu \mathrm{L}$ of protein calibration standard II (Bruker Daltonics) containing the following proteins: trypsinogen $(23,982 \mathrm{Da})$, protein $\mathrm{A}$ (44,613 Da) and bovine serum albumin (66,431 Da). All mass spectra were recorded by summing up to 400 laser shots. The Flex Analysis software packages provided by the manufacturer were used for data processing.

\section{Synthesis of OAg-cystamine-CRM 197 conjugates}

$40 \mathrm{mg}$ of $2192 \mathrm{OAg}$ were solubilized in $\mathrm{NaH}_{2} \mathrm{PO}_{4} 100 \mathrm{mM}$ pH $7.0(40 \mathrm{mg} / \mathrm{mL})$ and then cystamine $(110 \mathrm{mg} / \mathrm{mL}$, cystamine $/ \mathrm{OAg}(\mathrm{w} / \mathrm{w})=2.75)$ and $\mathrm{NaBH}_{3} \mathrm{CN}(61 \mathrm{mg} / \mathrm{mL}$, $\left.\mathrm{NaBH}_{3} \mathrm{CN} / \mathrm{OAg}(\mathrm{w} / \mathrm{w})=1.53\right)$ were added. The mixture was stirred for $3 \mathrm{~h}$ at $\mathrm{RT}$ and then desalted against water on a G-25 $53 \mathrm{~mL}$ column. Cystamine disulfide bond was reduced by mixing the $\mathrm{OAg}$ at a concentration of $20 \mathrm{mg} / \mathrm{mL}$ with DTT $100 \mathrm{mM}$ in $\mathrm{NaH}_{2} \mathrm{PO}_{4} 100 \mathrm{mM}$ EDTA $5 \mathrm{mM}$ for $1 \mathrm{~h}$ at RT. The derivatized $\mathrm{OAg}$ was purified by desalting on a G-25 53 $\mathrm{mL}$ column against $10 \mathrm{mM} \mathrm{NaH}_{2} \mathrm{PO}_{4} 5 \mathrm{mM}$ EDTA pH 7.5. The amination reaction with cystamine was also performed at higher scale on $100 \mathrm{mg}$ of $\mathrm{OAg}$ and the mixture purified by tangential flow filtration $\left(10 \mathrm{k} 200 \mathrm{~cm}^{2}\right.$ Hydrosart membrane, 10 diafiltration cycles vs. $\mathrm{NaCl}$ $1 \mathrm{M}$, followed by 10 cycles against water). 
Derivatized OAg intermediates were characterized by phenol sulfuric assay for sugar content [27] and by HPLC-SEC [23] for verifying absence of aggregation or degradation after modification. After the reaction with cystamine, the introduction of $\mathrm{NH}_{2}$ groups was verified by TNBS colorimetric method [25] using 6-aminohexanoic acid as standard and subtracting the number of $\mathrm{NH}_{2}$ groups already present on the un-derivatized OAg sample. Percentage of OAg chains activated was calculated as moles of linked cystamine/moles of KDO (calculated by HPLC-SEC/semicarbazide assay [22]) $\%$. After the reduction with DTT, introduction of SH groups was verified by Ellman analysis [28]. Activation on the terminus $\mathrm{KDO}$ was calculated as moles of linked $\mathrm{SH} /$ moles of $\mathrm{KDO} \%$, while the ratio \% between $\mathrm{SH}$ groups/cystamine moles gave the efficiency of reduction reaction with DTT.

Conjugation was performed solubilizing the derivatized OAg in $\mathrm{NaH}_{2} \mathrm{PO}_{4} 100 \mathrm{mM}$ EDTA $1 \mathrm{mM} \mathrm{pH} 7.2(10 \mathrm{mg} /$ $\mathrm{mL}$ ), using a molar ratio of thiol groups to $\mathrm{CRM}_{197}$ of 30 to 1. After mixing $\mathrm{ON}$ at RT, the mixture was purified by size exclusion chromatography with a Sephacryl S-300 h column $1.6 \mathrm{~cm} \times 90 \mathrm{~cm}$ [GE Healthcare], eluting with PBS pH 7.2 at $0.5 \mathrm{~mL} / \mathrm{min}$.

\section{Synthesis of OAg-propargylamine-CRM 197}

OAg $(40 \mathrm{mg})$ was solubilized in $\mathrm{NaH}_{2} \mathrm{PO}_{4} \mathrm{pH} 7.0(40 \mathrm{mg} /$ $\mathrm{mL})$, then propargylamine $(27.5 \mathrm{mg} / \mathrm{mL}$, propargylamine/ $\mathrm{OAg}(\mathrm{w} / \mathrm{w})=0.67)$ and $\mathrm{NaBH}_{3} \mathrm{CN}(62.8 \mathrm{mg} / \mathrm{mL}$, $\left.\mathrm{NaBH}_{3} \mathrm{CN} / \mathrm{OAg}(\mathrm{w} / \mathrm{w})=1.53\right)$ were added. The reaction was stirred for $3 \mathrm{~h}$ at RT and purified by desalting on a G-25 $53 \mathrm{~mL}$ column against water. Derivatized OAg intermediates were characterized by phenol sulfuric assay for sugar content [27] and by HPLC-SEC [23] for verifying absence of aggregation or degradation after modification.

Conjugation was performed adding by OAgpropargylamine to $\mathrm{CRM}_{197}-\mathrm{N}_{3}(5 \mathrm{mg} / \mathrm{mL}$, average of 5.2 Lysines activated) in $\mathrm{NaH}_{2} \mathrm{PO}_{4} 400 \mathrm{mM} \mathrm{pH} 7.2$ with THPTA $25 \mathrm{mM}$, sodium ascorbate $10 \mathrm{mM}$ and $\mathrm{CuSO}_{4}$. $5 \mathrm{H}_{2} \mathrm{O} 5 \mathrm{mM}$, with a molar ratio alkyne/azide $=5$. Reaction was stirred at RT for $6 \mathrm{~h}$ and conjugate formation followed by HPLC-SEC (TSK gel 6000PW + TSK gel 5000PW).

\section{Synthesis of OAg-ADH-BCNesterl-CRM 197}

OAg (40 mg) was solubilized in AcONa $100 \mathrm{mM} \mathrm{pH} 4.5$ (40 $\mathrm{mg} / \mathrm{mL})$, then $\mathrm{ADH}(48 \mathrm{mg} / \mathrm{mL}, \mathrm{ADH} / \mathrm{OAg}(\mathrm{w} / \mathrm{w})=1.2)$ and $\mathrm{NaBH}_{3} \mathrm{CN}\left(48 \mathrm{mg} / \mathrm{mL}, \mathrm{NaBH}_{3} \mathrm{CN} / \mathrm{OAg}(\mathrm{w} / \mathrm{w})=1.2\right)$ were added. The mixture was stirred for $2 \mathrm{~h}$ at $30{ }^{\circ} \mathrm{C}$ and then purified by desalting on a G-25 $53 \mathrm{~mL}$ column against water.

For introduction of the second linker, BCN NHS ester I, OAg$\mathrm{ADH}$ was dissolved in water/DMSO 1:9 $(\mathrm{v} / \mathrm{v})$ at a concentration of $50 \mathrm{mg} / \mathrm{mL}$. When the derivatized OAg was completely solubilized, TEA was added (molar ratio TEA/total $\mathrm{NH}_{2}$ groups $=5$; total $\mathrm{NH}_{2}$ groups included both phosphoethanolamine groups on the $\mathrm{OAg}$ and the hydrazide groups introduced with the linker $\mathrm{ADH}$ ) followed by Click easy BCN NHS ester I (molar ratio $\mathrm{BCN} N H S$ ester $\mathrm{I} /$ total $\mathrm{NH}_{2}$ groups $=12$ ). The solution was mixed at RT for $3 \mathrm{~h}$. The sample was purified by desalting on a G-25 53 $\mathrm{mL}$ column against water.

Derivatized OAg intermediates were characterized by phenol sulfuric assay for sugar content [27] and by HPLC-SEC [23] for verifying absence of aggregation or degradation after modification. Introduction of $\mathrm{NH}_{2}$ groups was verified by TNBS colorimetric method $[24,25]$ using ADH as standard and subtracting the number of $\mathrm{NH}_{2}$ groups already present on the underivatized OAg sample. Free ADH was detected by RP-HPLC [29]. The percentage of $\mathrm{OAg}$ chains activated was calculated as moles of linked $\mathrm{ADH}\left(\mathrm{NH}_{2}\right) /$ moles of $\mathrm{KDO} \%$ [22].

Total alkyne groups introduced with BCN NHS I were quantified by TNBS considering the residual number of unreacted $\mathrm{NH}_{2}$ groups remained after this derivatization step. Percentage of derivatization with BCN NHS I was calculated as molar ratio percentage of linked alkyne groups/total $\mathrm{NH}_{2}$ groups by TNBS before derivatization, indicating the percentage of moles of $\mathrm{NH}_{2}$ groups activated with this reaction.

For conjugation, $\mathrm{CRM}_{197}-\mathrm{N}_{3}$ at a concentration of $10 \mathrm{mg} /$ $\mathrm{mL}$ in PBS was added of OAg-ADH-BCNesterI (molar ratio alkyne/azide $=4$ ). Mixture was stirred for $6 \mathrm{~h}$ at RT. Conjugate purification was performed by hydrophobic interaction chromatography on a Phenyl HP column [GE Healthcare], loading $500 \mu \mathrm{g}$ of protein for $\mathrm{mL}$ of resin in $50 \mathrm{mM} \mathrm{NaH}{ }_{2} \mathrm{PO}_{4} 3 \mathrm{M} \mathrm{NaCl} \mathrm{pH} \mathrm{7.2.} \mathrm{The} \mathrm{purified} \mathrm{conjugate}$ was eluted in water and the collected fractions were dialysed against $10 \mathrm{mM} \mathrm{NaH}_{2} \mathrm{PO}_{4} \mathrm{pH}$ 7.2.

\section{OAg-CRM 197 conjugates characterization}

Total saccharide was quantified by phenol sulfuric assay [27], protein content by micro BCA and the ratio of saccharide to protein calculated. $\mathrm{OAg}-\mathrm{CRM}_{197}$ conjugates profiles were compared with free $\mathrm{CRM}_{197}$ and free OAg by HPLC-SEC. All samples were eluted on a TSK gel 6000PW $(30 \mathrm{~cm} \times 7.5$ $\mathrm{mm}$ ) column (particle size $17 \mu \mathrm{m}$; Sigma 8-05765) connected in series with a TSK gel 5000PW (30 cm x $7.5 \mathrm{~mm})$ column (particle size $17 \mu \mathrm{m}$; Sigma 8-05764) with TSK gel PWH guard column (7.5 mm ID x $7.5 \mathrm{~cm} \mathrm{~L}$; particle size $13 \mu \mathrm{m}$; Sigma 8-06732) (Tosoh Bioscience). The use of the two columns in series gave better separation of conjugate from free saccharide and protein, allowing the conjugate to enter into the column. The mobile phase was $0.1 \mathrm{M} \mathrm{NaCl}, 0.1 \mathrm{M} \mathrm{NaH}_{2} \mathrm{PO}_{4}$, $5 \% \mathrm{CH}_{3} \mathrm{CN}, \mathrm{pH} 7.2$ at the flow rate of $0.5 \mathrm{~mL} / \mathrm{min}$ (isocratic method for $60 \mathrm{~min}$ ). OAg peaks were detected by dRI, while UV detection at $214 \mathrm{~nm}$ and $280 \mathrm{~nm}$ was used for free protein and conjugate detection. Protein and conjugate peaks were also detected using tryptophan fluorescence (emission spectrum at $336 \mathrm{~nm}$, with excitation wavelength at $280 \mathrm{~nm}$ ). Free 
protein was estimated by HPLC-SEC, running a calibration curve of the unconjugated protein in the range $5-50 \mu \mathrm{g} / \mathrm{mL}$ under the same conditions as for the conjugate. The percentage of unconjugated $\mathrm{CRM}_{197}$ was calculated by dividing the amount of free protein detected by HPLC-SEC by the total amount of protein quantified in the sample by micro BCA. Free saccharide was verified to be lower than $20 \%$ by comparing eventual peak of free $\mathrm{OAg}$ in the conjugate with the peak of an OAg standard injected at the concentration corresponding to $20 \%$ of the total sugar amount as estimated by phenol sulfuric assay.

\section{Results}

\section{Thiol conjugation chemistry}

Thiol-conjugation chemistry was initially tested. The KDO moiety was targeted for introducing cystamine linker at the reducing end of the OAg chain without modifying the repeating units structure. After DTT-reduction, the activated OAg was conjugated to the carrier protein (Fig. 1).

OAg derivatization with cystamine was characterized by sugar recovery higher than $80 \%$. TNBS analysis indicated that $70-80 \%$ of OAg chains were activated. After DTT addition, sugar recovery was again higher than $75 \%$ and a complete reduction of the thiols was confirmed by the analysis of thiol groups introduced.

$\mathrm{CRM}_{197}$ was derivatized using different hetero bi-functional linkers, with a functional group able to react with the thiol unit introduced at the end of the OAg chain. Different amino acids were targeted, also trying to result in variable protein loading (Fig. 2A; Table 1). In all cases, protein recovery was higher than 90\%. Overall, derivatization on Lysine residues allow to introduce the highest number of linkers per mole of protein, respectively 8 using SBAP and 11.3 using EMCS (1-2, Table 1). Using controlled conjugation chemistries, an average of 3.1 lysines were instead targeted with EMCS (3, Table 1). Reaction of $\mathrm{CRM}_{197}$ with BMPH by EDAC chemistry resulted in the introduction of an average number of 3.4 linkers per protein (4, Table 1). When NHS was added to EDAC for activating the $\mathrm{COOH}$ groups on the protein, trying to increase the activation degree, an average of 5.1 linkers was introduced (5, Table 1). Tyrosines were also modified obtaining an average loading of 4.1 linkers per protein (6, Table 1).

Thiolated OAg was then conjugated to derivatized $\mathrm{CRM}_{197}$ characterized by different amino acids activated (Lys, Tyr or Glu/Asp) and different linker loading. Using this conjugation chemistry, it was not possible to obtain conjugate formation unless the number of linkers per protein was at least $8(1-2$, Table 1; Fig. 1).

The two conjugation reactions that succeeded, both based on lysine chemistry, were characterized by no presence of unreacted protein in the conjugation mixture. Even if the number of linkers per $\mathrm{CRM}_{197}$ was high (8 and 11.3), corresponding conjugates were characterized by a low OAg to protein molar ratio (1.6 and 2.7 respectively) (1-2, Table 1 ).

Looking at the HPLC-SEC profiles (dRI) of the conjugation mixtures, even when conjugation was successful, the presence of a sugar population at higher molecular weight was observed, probably deriving from oxidation of the thiolated OAg to generate a sugar dimer (not shown). Different methods were attempted to avoid the generation of the oxidation product, and hence of an unreactive OAg form, to see if this could then result in higher conjugation efficiency. Conjugation of DTT-treated OAg-cystamine with $\mathrm{CRM}_{197^{-}}$ BMPH under $\mathrm{N}_{2}$ caused precipitation of the protein; onepot-two-step OAg-cystamine reduction with TCEP as reducing agent and conjugation to $\mathrm{CRM}_{197}-\mathrm{BMPH}$ (5.2 linkers) was also not successful. When DTT-treated cystamine was conjugated with $\mathrm{CRM}_{197}-\mathrm{BMPH}$ in the presence of TCEP, the formation of the disulfide aggregate was avoided, however most of protein did not conjugate.

In summary thiol conjugation strategies did not allow to get all the panel of wanted conjugates and it became needed to identify a different conjugation approach.

\section{Click chemistry}

There are two main ways of performing the click 1,3-dipolar reaction: by using metal as a catalyst (usually copper), or alternatively lowering the activation barrier for $[3+2]$ cycloaddition by employing intrinsically highly strained cyclic alkynes that readily react with azide groups. For starting, both the approaches were compared for the reaction of the alkynederivatized $S$. Typhimurium OAg with $\mathrm{CRM}-\mathrm{N}_{3}$.

For the copper click chemistry, the OAg was derivatized with propargylamine by reductive amination on the terminal KDO (Fig. 3A). For the copper-free approach instead, the alkyne linker was introduced on the $\mathrm{OAg}-\mathrm{ADH}$, with activation higher $80 \%$ (Fig. 3B).

The inclusion of azido groups on $\mathrm{CRM}_{197}$ was initially performed by targeting lysines using NHS-PEG4$\mathrm{N}_{3}$ (Fig. 2B, controlled modification). Different loadings were obtained, in the range of 3.8-10 linker introduced per protein, depending on the amount of linker added. In all cases, protein recovery was higher than $90 \%$ (Table 2). $\mathrm{CRM}_{197}$ with an average number of 5.2 linkers introduced $\left(\mathrm{CRM}_{197}-\mathrm{N}_{3}\right.$ (LYS5.2)) was used at 5 $\mathrm{mg} / \mathrm{mL}$ for comparing these two approaches.

Despite a lower sugar to protein ratio, the copper free conjugation was more efficient (Table 3 ). In both cases, reaction time did not seem to have a strong impact on conjugate formation (Table 3). Because of the higher conjugation efficiency and to avoid the use of a toxic metal, the copper-free approach was selected for further experiments. 
Fig. 1 Thiol conjugation chemistry. Activation of the terminal KDO unit of the $\mathrm{OAg}$ chain with cysteamine and conjugation to activated-CRM $\mathrm{C}_{197}$
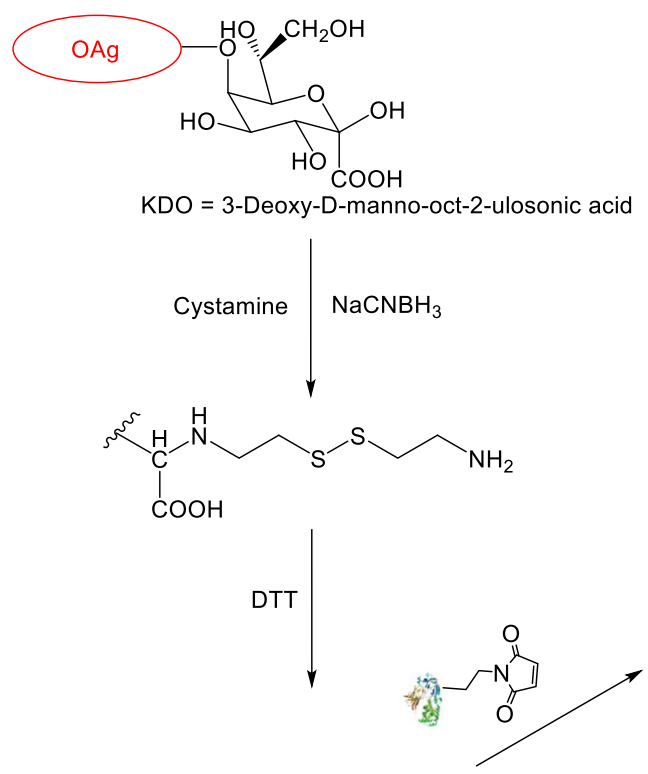<smiles>CCC(NCCSC1CC(=O)N(CCC#[W])C1=O)C(=O)O</smiles><smiles>CC(C)NCCS</smiles>

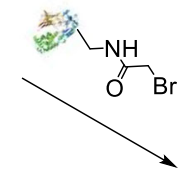

Maintaining protein concentration at $5 \mathrm{mg} / \mathrm{mL}$ and increasing the alkyne to azide molar ratio from 1 to 2 , conjugation efficiency was not altered after $6 \mathrm{~h}$ of reaction, with $78 \%$ of $\mathrm{CRM}_{197}$ conjugated (Table 4). Increasing protein concentration from 5 to 10 $\mathrm{mg} / \mathrm{mL}$ and the alkyne to azide molar ratio from 2 to 4 , conjugation became quantitative. When a protein with a higher average number of linkers was used (from 5.2 to 10 ), no free $\mathrm{CRM}_{197}$ was detected in the conjugation mixture (Table 4; Fig. 4).

The optimal conditions identified here for clickchemistry conjugation were applied for the synthesis of a panel of glycoconjugates differing for type of amino acid targeted and number of sites activated on the protein (Table 5; Fig. 2B) [6]. In order to compare the conjugates generated by the free-metal click and the thiol conjugation chemistry with a similar linker loading on the carrier protein, $\mathrm{CRM}_{197}$ with an average number of 7.1 linkers introduced $\left(\mathrm{CRM}_{197}-\mathrm{N}_{3}(\mathrm{LYS} 7.1)\right.$ ) was considered (7, Table 5). As previously reported, the conjugation to the alkyne-derivatized OAg was successful with all $\mathrm{CRM}_{197}$ conjugated and residual free $\mathrm{OAg}$ removed by purification through HIC (Table 5) [6]. The conjugate was characterized by a similar $\mathrm{OAg}$ to protein molar ratio (2.0) to what previously observed with thiol chemistry on activated lysine groups on $\mathrm{CRM}_{197}$. We have determined that click chemistry can be used for the synthesis of conjugate vaccines when the linker loading is low targeting both lysines and tyrosine that were immunogenic in mice (8-10 Table 5; Fig. 2B) [6]. Importantly, the reaction conditions allowed the conjugation with only one linker $\mathrm{CRM}_{197}-\mathrm{N}_{3}(\mathrm{LYS} 1)$, where $38 \%$ of $\mathrm{CRM}_{197}$ was conjugated after $6 \mathrm{~h}$ using a chemoenzymatic approach (8 Table 5; Fig. 2B selective modification).

As previously observed with $\mathrm{CRM}_{197}-\mathrm{N}_{3}$ (LYS5.2), the conjugation of $\mathrm{CRM}_{197}-\mathrm{N}_{3}$ (LYS1) is fast as increasing the reaction time from 2 to $6 \mathrm{~h}$ did not impact the conjugate formation (Table 6).

\section{Discussion}

The design of structurally defined glycoconjugates brings advantages in terms of physicochemical characterization of the vaccine and could lead to the selection of candidates with enhanced efficacy. With this regard, we have recently demonstrated that the conjugation site plays a role in determining the immunogenicity in mice and one single attachment point may be sufficient to induce high levels of bactericidal antibodies [6]. The use of structurally defined constructs with epitopes displayed at precise sites is also desirable to better understand the antigen presentation to the immune system and to rationalize the development of efficacious glycoconjugates vaccines. However, selective 
$\mathbf{a}$

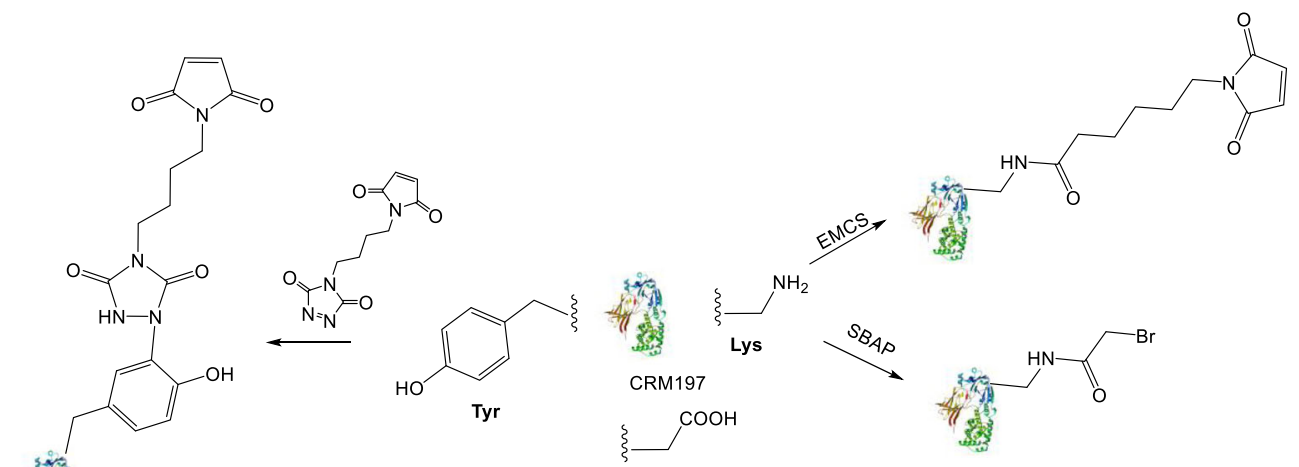

\section{b}<smiles>CC(C)OCCOC(C)Cn1c(=O)[nH]n(-c2cc(C[As]3C#CC[As]3)ccc2O)c1=O</smiles><smiles>CC(C)OCCOCCCn1c(=O)[nH][nH]c1=O</smiles><smiles>CCCc1ccc(O)cc1</smiles>

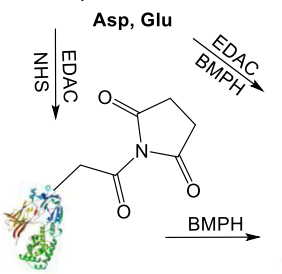<smiles>O=C(CCN1C(=O)C=CC1=O)NNC(=O)Cc1ccccc1</smiles>

Fig. 2 Activation of the carrier protein. (A) Thiol chemistry: $\mathrm{CRM}_{197}$ was derivatized on Lys, Tyr or Glu/Asp using different hetero bifunctional linkers able to react with cysteamine-activated OAg. (B)
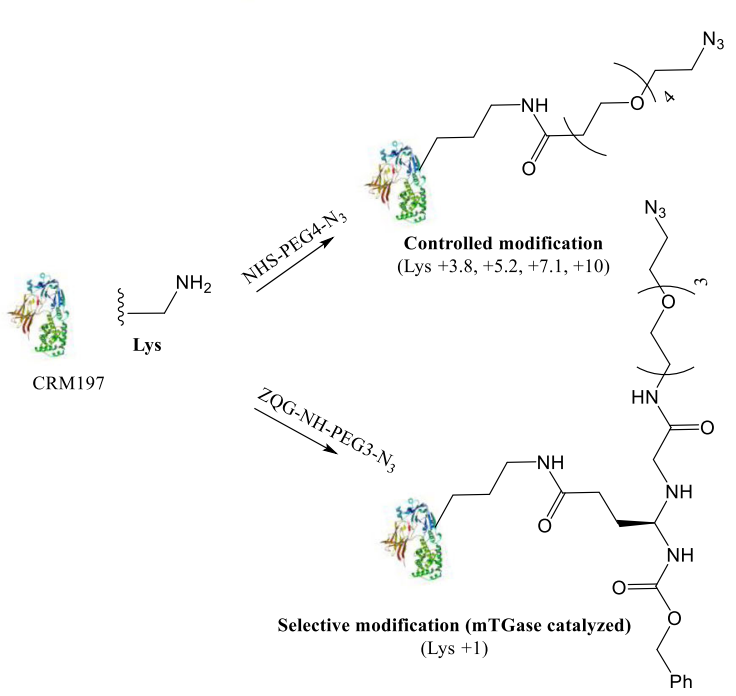

Click Chemistry: $\mathrm{CRM}_{197}$ was derivatized on Lys or Tyr with NHSPEG4- $\mathrm{N}_{3}$ to introduce azido groups. Lysine activation was performed by selective (Lys +1 ) or controlled modification (Lys)

Table 1 OAg-CRM197 conjugation by thiol chemistry

\begin{tabular}{|c|c|c|c|c|c|}
\hline Conjugate & Chemistry & Target & $\begin{array}{l}\text { Average } \\
\mathrm{CRM}_{197} \text { labeling }\end{array}$ & $\begin{array}{l}\text { OAg chains } \\
\text { per } \mathrm{CRM}_{197}\end{array}$ & $\begin{array}{l}\text { Conjugate } \\
(\%)\end{array}$ \\
\hline 1 - OAg-cysteamine-SBAP-CRM 197 & $\begin{array}{l}\text { Thiol } \\
\text { (Alkylation) }\end{array}$ & Lys & +8.0 & 1.6 & 100 \\
\hline 2 - OAg-cysteamine-EMCS-CRM 197 & $\begin{array}{l}\text { Thiol } \\
\text { (Addition) }\end{array}$ & Lys & +11.3 & 2.7 & 100 \\
\hline 3 - OAg-cysteamine-EMCS-CRM 197 & $\begin{array}{l}\text { Thiol } \\
\text { (Addition) }\end{array}$ & Lys & +3.1 & - & No \\
\hline 4 - OAg-cysteamine-BMPH-CRM ${ }_{197}$ & $\begin{array}{l}\text { Thiol } \\
\text { (Addition) }\end{array}$ & Glu/Asp & +3.4 & - & No \\
\hline 5 - OAg-cysteamine-(NHS)BMPH-CRM 197 & $\begin{array}{l}\text { Thiol } \\
\text { (Addition) }\end{array}$ & Glu/Asp & +5.1 & - & No \\
\hline 6 - OAg-cysteamine-maleimide-CRM ${ }_{197}$ & $\begin{array}{l}\text { Thiol } \\
\text { (Addition) }\end{array}$ & Tyr & +4.1 & - & No \\
\hline
\end{tabular}


$\mathbf{a}$

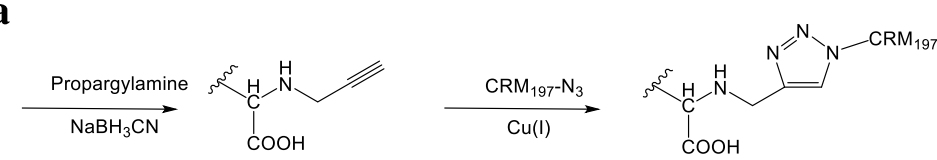

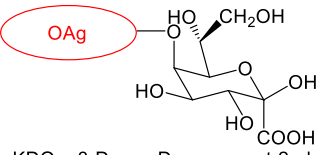

$\mathrm{KDO}=$ 3-Deoxy-D-manno-oct-2-ulosonic acid

b

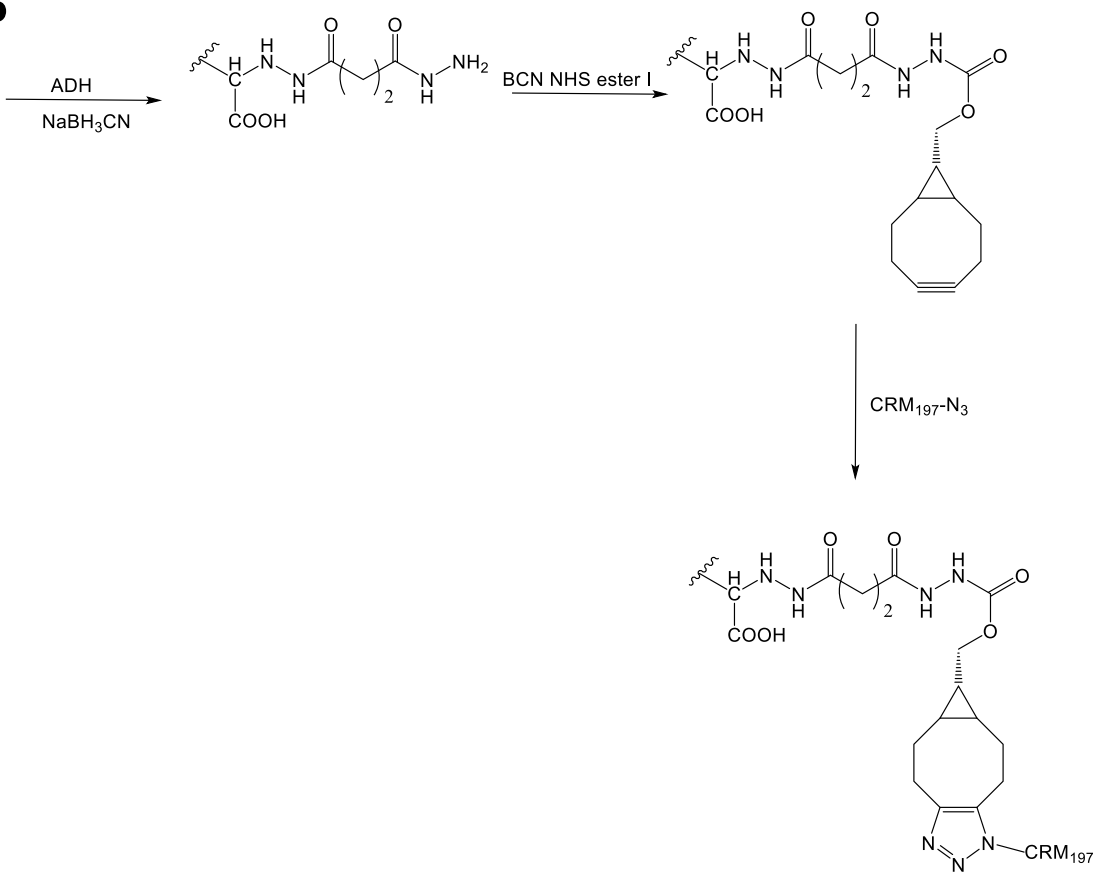

Fig. 3 Click conjugation chemistry. Two conjugation strategies: (A) Copper-free click reaction. (B) Copper-catalyzed click reaction

chemistries are usually characterized by lower conjugation efficiency than random ones.

The possibility of applying click chemistry [30] in bioconjugation was first demonstrated for the preparation of peptidotriazoles via solid phase synthesis [31]. Recently, it has been applied to the synthesis of glycoconjugate vaccines $[5,6,18,32]$. One of these reactions, the Huisgen 1,3-dipolar cycloaddition [33], has become the most popular click reaction, especially

Table 2 CRM197 controlled modification by azide insertion on lysines

\begin{tabular}{lll}
\hline $\begin{array}{l}\text { Linker:lysine ratio } \\
(\mathrm{mol} / \mathrm{mol})\end{array}$ & $\begin{array}{l}\text { Theoretical Lys } \\
\text { labelling* }\end{array}$ & $\begin{array}{l}\text { Average Lys } \\
\text { labelling }\end{array}$ \\
\hline 0.14 & +5.5 & +3.8 \\
0.18 & +7.0 & +5.2 \\
0.26 & +10.1 & +7.1 \\
0.39 & +15.2 & +10 \\
\hline
\end{tabular}

*Calculated considering 39 lysines on $\mathrm{CRM}_{197}$ because it can proceed rapidly at room temperature by employing copper as a catalyst $[31,34]$. It is characterized by mild reaction conditions, high yields and simple workup, selectivity, specificity and can be usually performed in water. One of the most important properties of the click chemistry is its bio-orthogonality. The azide moiety is

Table 3 Reaction conditions used for the comparison of copper-free and copper-catalyzed conjugation

\begin{tabular}{llll}
\hline Copper & $\begin{array}{l}\text { Alkyne:azide } \\
\text { ratio (mol/mol) }\end{array}$ & $\begin{array}{l}\text { Reaction } \\
\text { time } \\
(\mathrm{h})\end{array}$ & $\begin{array}{l}\text { Conjugate } \\
(\%)\end{array}$ \\
\hline Yes & 5 & 2 & 28 \\
& & 4 & 36 \\
No & 1 & 6 & 40 \\
& & 2 & 69 \\
& & 4 & 75 \\
\hline
\end{tabular}

$\mathrm{CRM}_{197}-\mathrm{N}_{3}(\mathrm{LYS} 5.2)$ at $5 \mathrm{mg} / \mathrm{ml}$ 
Table 4 Reaction conditions optimized for the copper-free conjugation

\begin{tabular}{llll}
\hline $\begin{array}{l}\text { Azide per } \\
\mathrm{CRM}_{197}\end{array}$ & $\begin{array}{l}{\left[\mathrm{CRM}_{197}\right]} \\
(\mathrm{mg} / \mathrm{mL})\end{array}$ & $\begin{array}{l}\text { Alkyne:azide } \\
(\mathrm{mol} / \mathrm{mol})\end{array}$ & $\begin{array}{l}\text { Conjugate } \\
(\%)\end{array}$ \\
\hline 5.2 & 5 & $1: 1$ & 78 \\
5.2 & 5 & $2: 1$ & 78 \\
5.2 & 10 & $4: 1$ & 90 \\
10 & 10 & $4: 1$ & 100 \\
\hline
\end{tabular}

Reaction time is $6 \mathrm{~h}$

absent in almost all naturally existing compounds, lacks reactivity with natural biomolecules and undergoes ligation only with a limited set of functionalities, such as alkyne groups. The sulfhydryl group is a popular target in many modification strategies. The frequency of sulfhydryl occurrence in proteins or other molecules is usually very low compared to other groups like amines or carboxylates. Therefore, the use of sulfhydryl-reactive chemistries can also restrict modification to only a limited number of sites within a target molecule.

In this study we have screened different click and thiol conjugation chemistries with the aim to identify a powerful conjugation methodology for the synthesis of site-selective glycoconjugates targeting one single point of the saccharide chain and one-to-few points of attachment on the carrier protein. We have used $S$. Typhimurium OAg and $\mathrm{CRM}_{197}$ as carbohydrate hapten and carrier protein models. It is worth mentioning that $S$. Typhimurium $\mathrm{OAg}$ and $\mathrm{CRM}_{197}$ are large molecules (20.5 $\mathrm{kDa}$ and $58.4 \mathrm{kDa}$, respectively), therefore the possibility to design site-selective constructs is hardly challenged by steric hindrance factors. Click chemistry has proved to be a more powerful tool in this sense, allowing the synthesis of conjugates even where only one position on the protein was available for linkage to the KDO unit of the sugar chain. When using thiolchemistry, we were not successful in obtaining glycoconjugates unless the number or linkers on the protein was at least 8 . Possible reasons to explain this behavior could be related with the instability of the functional groups on the linker in the presence of $\mathrm{CRM}_{197}$ and the verified oxidation of thiolated $\mathrm{OAg}$ in the conjugation conditions.

Indeed, insertion of thiol groups in meningococcal $\mathrm{C}$ oligomers followed by thiol-maleimide conjugation on $\mathrm{CRM}_{197}$ has been previously shown feasible, although the conjugation with $\mathrm{CRM}_{197}$-EMCS (6.5 linker per protein) reaction linked on average only 1.8 oligosaccharides per protein. In our work we have confirmed that conjugation of $S$. Typhimurium $\mathrm{OAg}$ to $\mathrm{CRM}_{197^{-}}$ EMCS is feasible, provided that a high number of linkers per protein are present $(+11.3)$, resulting in a conjugate bearing about $2.7 \mathrm{OAg}$ chain per protein. We did not observe conjugation in the presence of only 3.1 linker per protein. While in our investigation we did not test $\mathrm{CRM}_{197}$-EMCS with an average of 6.5 linkers and we have used a longer sugar model (20.5 vs. 4.5 $\mathrm{kDa}$ ), we think that both finding underline how, in the presence of thiol chemistry, the synthesis of conjugate vaccine with a controlled number of glycopeptide linkages may present some issues [35]. In addition, work from Nilo et al. confirmed that thiol-maleimide chemistry resulted in lower sugar loading on $\mathrm{CRM}_{197}$ compared to copper-free conjugation [26].

Copper-free chemistry was preferred because it produced better conjugation yields in preliminary tests and avoids the use of a toxic metal. Differently from the thiol chemistry tested, copper-free click chemistry allowed the linkage of the terminal sugar end of the $\mathrm{OAg}$ chain to the protein with high conjugation yields (higher than 80\%) even when few linkers were present on the protein (average number of 4) and to have conjugate formation with just one linker on the protein ( $38 \%$ of $\mathrm{CRM}_{197}$ conjugated). It is important also to consider that the conditions tested for the thiol chemistry have an intrinsic bias, since they used higher concentration of both $\mathrm{OAg}$ and protein, and higher molar ratio of active groups of OAg per linker on the carrier protein. The click conjugation proceeds with a fast rate with the reaction completed in only $2 \mathrm{~h}$ even when only
Fig. 4 HPLC-SEC profiles of OAg-ADH-BCNesterI-CRM 197 conjugation with $\mathrm{CRM}_{197^{-}}$ $\mathrm{N}_{3}$ (LYS5.2), green, or $\mathrm{CRM}_{197^{-}}$ $\mathrm{N}_{3}$ (LYS10), blue, in comparison to free $\mathrm{CRM}_{197}$, black.

Conjugation mixture were analyzed after $6 \mathrm{~h}$ at RT, using carrier protein at $10 \mathrm{mg} / \mathrm{mL}$ and alkyne/azide molar ratio of 4

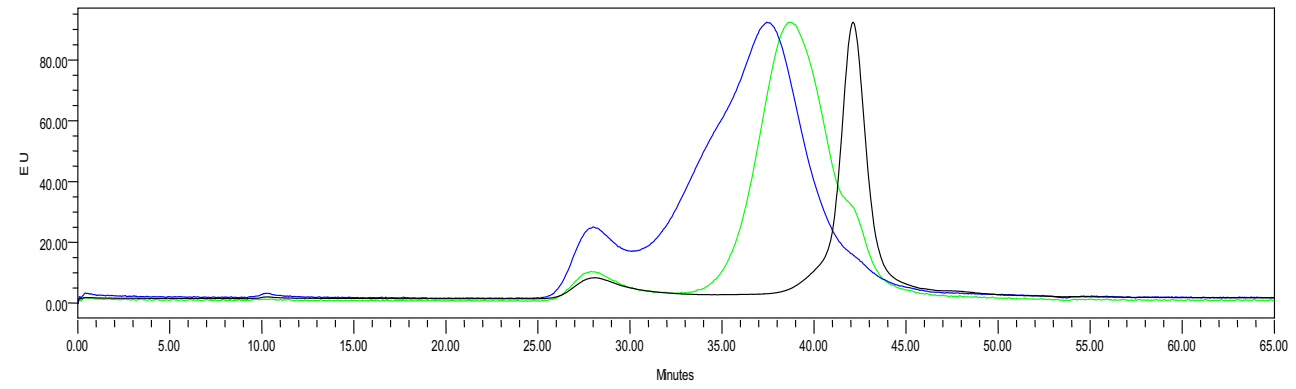


Table 5 OAg-CRM197 conjugation by click chemistry

\begin{tabular}{|c|c|c|c|c|c|}
\hline Conjugate & Chemistry & Target & $\begin{array}{l}\text { Average } \\
\text { CRM }_{197} \text { labeling }\end{array}$ & $\begin{array}{l}\text { OAg chains } \\
\text { per } \mathrm{CRM}_{197}\end{array}$ & $\begin{array}{l}\text { Conjugate } \\
(\%)\end{array}$ \\
\hline 7 - OAg-ADH-BCNesterI-CRM 197 & $\begin{array}{l}\text { Click } \\
\text { (Copper-free) }\end{array}$ & Lys & +7.1 & 2.0 & 100 \\
\hline 8 - OAg-ADH-BCNesterI-CRM ${ }_{197}$ & $\begin{array}{l}\text { Click } \\
\text { (Copper-free) }\end{array}$ & Lys & +1 & 0.7 & 31 \\
\hline 9 - OAg-ADH-BCNesterI-CRM 197 & $\begin{array}{l}\text { Click } \\
\text { (Copper-free) }\end{array}$ & Lys & +3.8 & 1.5 & 91 \\
\hline 10 - OAg-ADH-BCNesterI-CRM 197 & $\begin{array}{l}\text { Click } \\
\text { (Copper-free) }\end{array}$ & Tyr & +4.3 & 3.7 & 81 \\
\hline *Data from [6] & & & & & \\
\hline
\end{tabular}

one linker is present on the carrier protein. However, the linkers used for the synthesis of click and thiol conjugates were different, and an impact of the type of linker on conjugate formation cannot be excluded. While it has been previously reported that the linkers used for thiol-maleimide addition induced a lower antilinker response compared to the cyclooctene ring generated by SPAAC [26], our group has previously shown how conjugate with even only one sugar moiety per protein synthesized by copper-free click reaction can induce strong immunogenicity [6].

In order to generalize the outcome of the comparison between thiol and click chemistries, different sugar and - more importantly - protein models should be investigated. While we would expect different carrier proteins to behave differently, we think that the outcome of the current investigation will likely apply to the diphtheria toxoid (DT), another commonly used carrier protein, structurally related to $\mathrm{CRM}_{197}$.

In conclusion, we compared thiol and click chemistry for the synthesis of site-selective conjugates on the OAg. Click chemistry allows the synthesis of glycoconjugates where different amino acid can be targeted and in a different number, impacting the number of sugar present per carrier protein and the immunogenicity [6]. Click chemistry is therefore a powerful tool for the synthesis of glycoconjugate vaccines as it allows the investigation of different parameters important for the immunogenicity.

Table 6 Effect of reaction time on copperfree click conjugation with CRM197N3(LYS1)
Acknowledgements The authors thank Dr. Qi-Ying Hu and Zachary Robinson (former Novartis Institutes for BioMedical Research) for assistance during the synthesis of the compounds OAg-ADH-BCNesterI$\mathrm{CRM}_{197}(\mathrm{Lys}+1)$ and OAg-cysteamine-maleimide-CRM $\mathrm{C}_{197}$.

\section{Compliance with ethical standards}

Conflicts of interest The authors declare that they have no conflicts of interest.

Ethical approval This article does not contain any studies with human participants or animals performed by any of the authors.

Open Access This article is licensed under a Creative Commons Attribution 4.0 International License, which permits use, sharing, adaptation, distribution and reproduction in any medium or format, as long as you give appropriate credit to the original author(s) and the source, provide a link to the Creative Commons licence, and indicate if changes were made. The images or other third party material in this article are included in the article's Creative Commons licence, unless indicated otherwise in a credit line to the material. If material is not included in the article's Creative Commons licence and your intended use is not permitted by statutory regulation or exceeds the permitted use, you will need to obtain permission directly from the copyright holder. To view a copy of this licence, visit http://creativecommons.org/licenses/by/4.0/.

\section{References}

1. Avci, F.Y., Kasper, D.L.: How bacterial carbohydrates influence the adaptive immune system. Annu. Rev. Immunol. 28:107-130 (2010) https://doi.org/10.1146/annurev-immunol-030409-101159

2. Pace, D.: Glycoconjugate vaccines. Expert. Opin. Biol. Ther. 13(1): 11-33 (2013) https://doi.org/10.1517/14712598.2012.725718 ([doi])

3. Costantino, P., Rappuoli, R., Berti, F.: The design of semi-synthetic and synthetic glycoconjugate vaccines. Expert. Opin. Drug Discov. 6(10):1045-1066 (2011) https://doi.org/10.1517/17460441.2011. 609554

4. Bernardes, G.J., Castagner, B., Seeberger, P.H.: Combined approaches to the synthesis and study of glycoproteins. ACS Chem. Biol. 4(9): 703-713 (2009) https://doi.org/10.1021/cb900014n

5. Adamo, R., Nilo, A., Castagner, B., Boutureira, O., Berti, F., Bernardes, G.J.L.: Synthetically defined glycoprotein vaccines: current status and future directions. Chem. Sci. 4:2995 (2013) 
6. Stefanetti, G., Rondini, S., Lanzilao, L., Saul, A., MacLennan, C.A., Micoli, F.: Sugar-protein connectivity impacts on the immunogenicity of site-selective Salmonella O-antigen glycoconjugate vaccines. Angew Chem Int Ed Engl (2015) https://doi.org/10. 1002/anie.201506112

7. Grayson, E.J., Bernardes, G.J., Chalker, J.M., Boutureira, O., Koeppe, J.R., Davis, B.G.: A coordinated synthesis and conjugation strategy for the preparation of homogeneous glycoconjugate vaccine candidates. Angew. Chem. Int Ed Engl. 50(18):4127-4132 (2011) https://doi.org/10.1002/anie.201006327 ([doi])

8. Adamo, R., Hu, Q.-Y., Torosantucci, A., Crotti, S., Brogioni, G., Allan, M., Chiani, P., Bromuro, C., Quinn, D., Tontini, M., Berti, F.: Deciphering the structure-immunogenicity relationship of antiCandida glycoconjugate vaccines. Chem. Sci. 5(11):4302-4311 (2014) https://doi.org/10.1039/C4SC01361A

9. Nilo, A., Allan, M., Brogioni, B., Proietti, D., Cattaneo, V., Crotti, S., Sokup, S., Zhai, H., Margarit, I., Berti, F., Hu, Q.Y., Adamo, R.: Tyrosine-directed conjugation of large glycans to proteins via copper-free click chemistry. Bioconjug Chem. 25(12), 2105-2111 (2014). https://doi.org/10.1021/bc500438h

10. Feasey, N.A., Dougan, G., Kingsley, R.A., Heyderman, R.S., Gordon, M.A.: Invasive non-typhoidal salmonella disease: an emerging and neglected tropical disease in Africa. Lancet 379(9835), 2489-2499 (2012) https://doi.org/10.1016/S01406736(11)61752-2

11. Reddy, E.A., Shaw, A.V., Crump, J.A.: Community-acquired bloodstream infections in Africa: a systematic review and metaanalysis. Lancet Infect. Dis. 10(6), 417-432 (2010) https://doi. org/10.1016/S1473-3099(10)70072-4

12. Stefanetti, G., Rondini, S., Lanzilao, L., Saul, A., MacLennan, C.A., Micoli, F.: Impact of conjugation chemistry on the immunogenicity of S. Typhimurium conjugate vaccines. Vaccine. 32(46), 6122-6129 (2014) https://doi.org/10.1016/j.vaccine.2014.08.056

13. Simon, R., Tennant, S.M., Wang, J.Y., Schmidlein, P.J., Lees, A., Ernst, R.K., Pasetti, M.F., Galen, J.E., Levine, M.M.: Salmonella enterica serovar enteritidis core $\mathrm{O}$ polysaccharide conjugated to $\mathrm{H}$ : $\mathrm{g}, \mathrm{m}$ flagellin as a candidate vaccine for protection against invasive infection with S. enteritidis. Infect. Immun. 79(10), 4240-4249 (2011) https://doi.org/10.1128/IAI.05484-11

14. MacLennan, C.A., Martin, L.B., Micoli, F.: Vaccines against invasive Salmonella disease: Current status and future directions. Hum. Vaccin. Immunother. 10(6), 29054 (2014)

15. Rondini, S., Micoli, F., Lanzilao, L., Gavini, M., Alfini, R., Brandt, C., Clare, S., Mastroeni, P., Saul, A., MacLennan, C.A.: Design of glycoconjugate vaccines against invasive African Salmonella enterica serovar Typhimurium. Infect Immun. 83(3), 996-1007 (2015) https://doi.org/10.1128/iai.03079-14

16. Broker, M., Costantino, P., DeTora, L., McIntosh, E.D., Rappuoli, R.: Biochemical and biological characteristics of cross-reacting material 197 CRM197, a non-toxic mutant of diphtheria toxin: use as a conjugation protein in vaccines and other potential clinical applications. Biologicals. 39(4), 195-204 (2011) https://doi.org/10.1016/j. biologicals.2011.05.004

17. Shinefield, H.R.: Overview of the development and current use of CRM(197) conjugate vaccines for pediatric use. Vaccine. 28(27), 4335-4339 (2010) https://doi.org/10.1016/j.vaccine.2010.04.072

18. Hu, Q.-Y., Allan, M., Adamo, R., Quinn, D., Zhai, H., Wu, G., Clark, K., Zhou, J., Ortiz, S., Wang, B., Danieli, E., Crotti, S., Tontini, M., Brogioni, G., Berti, F.: Synthesis of a well-defined glycoconjugate vaccine by a tyrosine-selective conjugation strategy. Chem. Sci. 4, 3827-3832 (2013)

19. Verez-Bencomo, V., Fernandez-Santana, V., Hardy, E., Toledo, M.E., Rodriguez, M.C., Heynngnezz, L., Rodriguez, A., Baly, A., Herrera, L., Izquierdo, M., Villar, A., Valdes, Y., Cosme, K., Deler, M.L., Montane, M., Garcia, E., Ramos, A., Aguilar, A., Medina, E., Torano, G., Sosa, I., Hernandez, I., Martinez, R., Muzachio, A.,
Carmenates, A., Costa, L., Cardoso, F., Campa, C., Diaz, M., Roy, R.: A synthetic conjugate polysaccharide vaccine against Haemophilus influenzae type b. Science 305(5683), 522-525 (2004) https://doi.org/10.1126/science.1095209

20. Marburg, S., Jorn, D., Tolman, R.L., Arison, B., McCauley, J., Kniskern, P.J., Hagopian, A., Vella, P.P.: Bimolecular chemistry of macromolecules: synthesis of bacterial polysaccharide conjugates with Neisseria meningitidis membrane protein. J. Am. Chem. Soc. 108(17), 5282-5287 (1986) https://doi.org/10.1021/ ja00277a037

21. Peeters, C.C., Evenberg, D., Hoogerhout, P., Kayhty, H., Saarinen, L., van Boeckel, C.A., van der Marel, G.A., van Boom, J.H., Poolman, J.T.: Synthetic trimer and tetramer of 3-beta-D-ribose(1-1)-D-ribitol-5-phosphate conjugated to protein induce antibody responses to Haemophilus influenzae type $\mathrm{b}$ capsular polysaccharide in mice and monkeys. Infect. Immun. 60(5), 1826-1833 (1992)

22. Micoli, F., Rondini, S., Gavini, M., Pisoni, I., Lanzilao, L., Colucci, A.M., Giannelli, C., Pippi, F., Sollai, L., Pinto, V., Berti, F., MacLennan, C.A., Martin, L.B., Saul, A.: A scalable method for O-antigen purification applied to various Salmonella serovars. Anal. Biochem. 434(1), 136-145 (2013) https://doi.org/10.1016/j. ab.2012.10.038

23. Micoli, F., Ravenscroft, N., Cescutti, P., Stefanetti, G., Londero, S., Rondini, S., MacLennan, C.A.: Structural analysis of Opolysaccharide chains extracted from different Salmonella Typhimurium strains. Carbohydr.Res. 385, 1-8 (2014) https://doi. org/10.1016/j.carres.2013.12.003

24. Satake, K., Okuyamna, T., Ohashi, ,M., Shinoda, T.: The spectrophotometric determination of amine, amino acid and peptide with 2, 4,6-trinitrobenzene 1-sulfonic acid. In: Satake, K., Okuyamna,T., Ohashi,M.,and Shinoda,T. (ed.) J. Biochem., vol. 47. pp. 654-660. (1960)

25. Palmer, D.W., Peters, T. Jr.: Automated determination of free amino groups in serum and plasma using 2,4,6-trinitrobenzene sulfonate. Clin. Chem. 15(9), 891-901 (1969)

26. Nilo, A., Passalacqua, I., Fabbrini, M., Allan, M., Usera, A., Carboni, F., Brogioni, B., Pezzicoli, A., Cobb, J., Romano, M.R., Margarit, I., Hu, Q.Y., Berti, F., Adamo, R.: Exploring the Effect of Conjugation Site and Chemistry on the Immunogenicity of an antiGroup B Streptococcus Glycoconjugate Vaccine Based on GBS67 Pilus Protein and Type V Polysaccharide. Bioconjug. Chem. 26(8), 1839-1849 (2015) https://doi.org/10.1021/acs.bioconjchem. $5 \mathrm{~b} 00365$

27. M, D., JK, K.A.G.: H., PA, R., F, S.: Colorimetric Method for Determination of Sugars and Related Substances. Anal. Chem. 28, 350 (1956)

28. ELLMAN, G.L.: Tissue sulfhydryl groups. Arch. Biochem. Biophys. 82(1), 70-77 (1959)

29. Micoli, F., Rondini, S., Gavini, M., Lanzilao, L., Medaglini, D., Saul, A., Martin, L.B.: O:2-CRM(197) conjugates against Salmonella Paratyphi A. PLoS One. 7(11), e47039 (2012) https:// doi.org/10.1371/journal.pone.0047039

30. Kolb, H.C., Finn, M.G., Sharpless, K.B.: Click Chemistry: Diverse Chemical Function from a Few Good Reactions. Angew. Chem. Int. Ed Engl. 40(11), 2004-2021 (2001) https://doi.org/10.1002/ 1521-3773(20010601)40:11<2004::aid-anie2004>3.3.co;2-x

31. Tornoe, C.W., Christensen, C., Meldal, M.: Peptidotriazoles on solid phase: [1,2,3]-triazoles by regiospecific copper(i)-catalyzed 1,3-dipolar cycloadditions of terminal alkynes to azides. J. Org. Chem. 67(9), 3057-3064: (2002)

32. Stefanetti, G., Saul, A., MacLennan, C.A., Micoli, F.: Click Chemistry Applied to the Synthesis of Salmonella Typhimurium O-Antigen Glycoconjugate Vaccine on Solid Phase with Sugar Recycling. Bioconjug. Chem. 26(12), 2507-2513 (2015) https:// doi.org/10.1021/acs.bioconjchem.5b00521 
33. Huisgen, R.: Kinetics and Mechanism of 1,3-Dipolar Cycloadditions. Angew. Chem. Int. Ed Engl. 2(11), 633-645 (1963) https://doi.org/10.1002/anie.196306331

34. Rostovtsev, V.V., Green, L.G., Fokin, V.V., Sharpless, K.B.: A stepwise huisgen cycloaddition process: copper(I)-catalyzed regioselective "ligation" of azides and terminal alkynes. Angew. Chem. Int Ed Engl. 41(14), 2596-2599 (2002) https://doi.org/10.1002/ 1521-3773(20020715)41:14<2596::AID-ANIE2596>3.0.CO;2-4

35. Adamo, R., Nilo, A., Harfouche, C., Brogioni, B., Pecetta, S., Brogioni, G., Balducci, E., Pinto, V., Filippini, S., Mori, E.,
Tontini, M., Romano, M.R., Costantino, P., Berti, F.: Investigating the immunodominance of carbohydrate antigens in a bivalent unimolecular glycoconjugate vaccine against serogroup A and C meningococcal disease. Glycoconj. J. 31(9), 637-647 (2014) https://doi.org/10.1007/s10719-014-9559-1

Publisher's note Springer Nature remains neutral with regard to jurisdictional claims in published maps and institutional affiliations. 